\title{
Erasmus staff exchanges: A critical exploration of intentions and effects
}

\author{
Paul G. Nixon
}

\section{Contact}

The Hague University of Applied Sciences Johanna Westerdijkplein 75

2521 EN The Hague

The Netherlands

P.G.Nixon@hhs.nl

\begin{abstract}
This article outlines the expected benefits of ERASMUS+ Teaching/Training Exchanges for individuals, the institution as a whole and the degree programmes of The Hague University of Applied Sciences (THUAS), the Netherlands. The method employed was a series of semi-structured interviews, following initial email contact of 32 (approx. $1.5 \%$ of staff) who had been on exchange, or were scheduled to be, during the academic year. Interviews were agreed with 7 staff. Leask (2015) identified a lack of research in this area, and it is hoped this research will help to stimulate thinking on this issue. Despite the small sample size, general preliminary conclusions can be drawn and further research is encouraged. The article examines processes and procedures in place for monitoring such exchanges, and it also explores control and monitoring prior to the exchange taking place, as well as post-exchange outcomes and evaluations. It describes the context and theoretical frameworks and discusses the major findings, including accounts of the participants' experiences and the benefits for them as individuals, their perceptions, their line manager's responses and institutional policies and processes. The conclusion has recommendations for improvement based upon the participants' comments. The main message of this article is the need to set goals for the individual and the institution and to evaluate them upon return.
\end{abstract}

Keywords: staff exchange, policy, implementation, feedback, outcomes

\section{Výměna zaměstnanců $v$ rámci programu Erasmus: Kritický průzkum záměrů a efektivity} Abstrakt: Cílem této př́ípadové studie je vysvětlení a pochopení
očekávaných př́nosů výměnných programů ERASMUS+ Teaching
nebo Training jak pro jednotlivé účastníky, tak pro instituce
a programy. Dotyčnou institucí je Hague University of Applied
Sciences (THUAS) sídlící v nizozemském Haagu. Studie se snaží
objasnit, zda skutečně došlo ke splnění očekávání. Zkoumá
procesy a postupy stanovené pro monitorování takových výměn
a prozkoumává stupeň kontroly a monitorování potenciálu před
uskutečněním výměny, a také kontrolu a monitorování výstupů,
př́ležitostí po ukončení výměny a následné vyhodnocení.
Následující sekce popisují kontext a teoretické rámce vycházející
z různorodých perspektiv podporujících tuto studii. Poté jsou 
$\triangle$ Correspondence: P.G.Nixon@hhs.nl

Copyright (C) 2021 by the author and publisher, TBU in Zlín.

This work is licensed under the Creative Commons Attribution International License (CC BY).

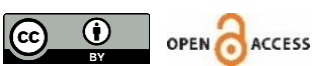

rozebírány metody výzkumu. Dále studie prezentuje a rozebírá hlavní zjištění včetně citací zkušeností účastníků jak ohledně interakce při výměně a prínosů pro účastníky jako jednotlivce, tak také ohledně jejich vnímání reakcí prímého nadřízeného a strategií a procesů instituce. Následují závěrečné postřehy a série doporučení na zlepšení managementu na základě př́padové studie názorů a pozorování účastníků. Leask (2015) identifikovala nedostatečný výzkum tohoto kontextu a doufáme, že tato prípadová studie pomůže, byt' i $v$ malém rozsahu, vyrovnat nerovnováhu a osvítit smýšlení o této problematice.

Klíčová slova: výměna zaměstnanců, politika, implementace, zpětná vazba, výsledky

\section{Introduction}

Erasmus+ KA 103 is the European Union's key 'mobility' programme in education and training and one of the few EU programmes widely recognised by the general public. It has undergone a number of revisions during the lifespan of the programme and now forms part of the Lifelong Learning programme (Cairns, 2017; "Education and Culture," 2015a, 2015b). A further update and revision of the programme is now being crafted that will take much more account of notions of virtual mobility, emphasising the increasing incorporation of the notion of internationalisation at home as a concept in order to enhance the reach of the programme beyond those who would be able to participate in its actual physical international mobility exchanges, and to include those who for a number of reasons may be unable to undertake such mobility. In its present form the Erasmus Programme fosters support of Learning Mobility for Individuals, Cooperation for Innovation and Exchange of Good Practices, and Support for Policy Reform. This is normally evidenced in student mobility, teacher/staff mobility, joint curriculum development, and intensive teaching programmes. This investment in knowledge, skills, and competences will benefit individuals, institutions, organizations and society as a whole by contributing to growth and ensuring equity, prosperity and social inclusion in Europe and beyond ("The new Erasmust," 2021). During the programmes, individuals encounter new situations that will aid "their educational, academic and professional development" ("Education and Culture," 2015b). Because of these (international) aims it can thus be seen as a tool of social education, for it further enhances the (educational) development of its participants.

Staff mobility for academics and support staff provides an opportunity for academics, the focus of this paper, to travel to develop and enhance knowledge and skills, broaden perspectives and seek potential new avenues for personal and institutional cooperation in teaching and research, which can then be incorporated into the learning experiences of students at both the home and host institutions (Brandenburg, de Wit, Jones, \& Leask, 2019; Cushner \& Mahon, 2002). It also allows individuals to respond to the changing demands from the global labour market and society at large, which requires both educators and students to acquire updated skills and knowledge (Frisk, 2015; Schleicher, 2012). The rapid changes in society require new strategies and a concomitant re-evaluation of the role of higher education institutions in a globalised market, and of the ways in which they deliver content to students to meet their needs and address the challenges in front of us. There is a wide acceptance that "The global world is not built on national identities or marginalized kinship but rather inclusive values and 'no-border' strategies" ("Education and Culture," 2015a, 2015b) and thus there is a need for higher educational institutions to facilitate their staff to break out of national silos and learn from their peers (“European Union," 2014).

Leung (2013) and Jansone and Dislere (2016) note that global mobility of academics and other university staff helps to engender academic excellence. This is also a mechanism which aids staff in 
universities of applied sciences to keep up with the latest developments in their subjects and also in pedagogical practices by learning from their partners. Reflecting the way that knowledge economies, in general, have become more globally connected, staff mobility impacts both the individual and the institutions, with both benefitting from a wider perspective and the flexibility gained through travel and experiential learning during the mobility.

However, Sursock (2015) mentions the negative consequences of mobility that can impact upon an institution. They can lead to extra administrative burdens upon the institution's staff and to the creation of a mobile elite of lecturers who undertake mobility, as opposed to their colleagues who choose not to or are not offered the opportunity to be mobile. It is therefore important that the institution operates under a clear sense of purpose in such matters.

\subsection{THUAS and internationalisation}

The Hague University of Applied Sciences is situated in The Hague, Netherlands. As a university of applied sciences its primary role is as a teaching institution, although its research focus is now growing in line with Dutch government policy to encourage more applied research in universities of applied sciences. It has approx. 26,000 students and employs approx. 2,000 staff.

One of the things THUAS seeks to do is prepare students to be future professionals and global citizens capable of operating in a global, inclusive and changing environment. Thus, the field of internationalisation is of prime importance in the policies and activities of THUAS. Hunter and De Wit (2015) build upon Knight's definition of internationalisation (2004) and view it as being "the intentional process of integrating an international, intercultural or global dimension into the purpose, functions and delivery of post-secondary education, in order to enhance the quality of education and research for all students and staff, and to make a meaningful contribution to society" (Hunter \& De Wit, 2015).

THUAS policies on internationalisation include a recognition that in order to effect realistic change towards a goal of delivering global or international education (Quezada, 2012), there is a need to recognise the notion of internationalising the curriculum (Leask, 2015) or 'internationalisation at home'". For this, one needs the buy-in of academic staff who quite often, particularly at the onset of their career, may have little or no experience of teaching in an international classroom. This stretches far beyond the simple capability of being able to operate in a number of different languages, useful tools though they may be in internationalisation. These include such elements as a willingness to foster cross-national and cross-cultural partnerships and help students to further develop into their roles as dutifully conscientious citizens of their local and global habitats; knowledge, understanding and expertise in global issues and how they may impact upon one's students and shape the teaching one is expected to undertake; an understanding of different cultures and the capacity to be interculturally sensitive; and the ability to interculturally communicate knowledge and skills to students from diverse backgrounds and help them be aware of competing discourses. In short, one needs to engender a mindset that is open to flexible and, in these technologically driven times, repeated, if not constant, evaluation and change as evidenced by the THUAS slogan of "Let's Change. You. Us. The World." This manifests itself in such things as the design and implementation of international/multi-cultural research projects and collaborative online international learning opportunities (evidenced in THUAS as part of a range of COIL projects), which may also be aided by the incorporation of mobile students' prior experiences to enrich the diversity of input to the learner's educational experience.

This requires a willingness to be more inclusive, not just in terms of de-colonialization (Vorster \& Quinn, 2017) but also in terms of recognizing and integrating voices from groups who have often been nonprivileged into one's daily practices (Pett, 2015), encompassing diversity on the basis of issues such as race, gender, sexuality and class. One of the pre-requisites for THUAS to bring this about is to have a staff group who themselves share that same inquisitive openness about the wider society and recognise that higher education is not immune to, but operates within, an existing, but often fluctuating, political agenda. Recognising that, the staff group can then play a role in redesigning 
curricula, pedagogies and behaviours to better reflect and project the values of society and make the student experience more relevant by bringing about a wider systematic transformation of higher education.

As Lourenço notes, it is vital "to create times and spaces for academics to (re)construct knowledge in a collaborative way" (2018, p. 157). Leask (2015) has noted the way in which in-house training courses for new entrants to the profession have increasingly incorporated elements of international perspectives in the content, learning objectives, methodologies, and assessment strategy of study programmes. Academics sometimes struggle to reconcile broad overarching institutional policies and goals in relation to internationalisation with their own experiences, ambitions and disciplinary focus. This can often lead to a disconnect between those responsible for ensuring the smooth delivery of such institutional policies and goals, who are more often than not located in the international offices of service departments (Leask, Beelen, \& Kaunda, 2013), and the academics who are the lynchpin of any moves to internationalise educational delivery via any form of internationalisation of the curriculum (Sawir, 2011).

Erasmus+ Teaching/Training experiences are one key conduit through which the participants may easily engage with differing learning communities in order to share, gain and appraise the values of expertise, knowledge and pedagogical behaviours within contexts that may differ to varying extents to the 'norms' experienced in the 'home' institution. To use Archer's wider concept of a triumvirate of effects of culture, structure and people as being integral determinants of actions or outcomes (1995) and apply it to higher education situations, we can posit that observing and participating in educational delivery in different contexts and environments can also allow the participant to step outside of the constraints imposed by hierarchies, processes and procedures that are the norm at the home institution (Stohl, 2007) and sometimes outsides the constraints of subject specialisation. The Erasmus Impact Study, which included surveys of those staff taking part in outgoing staff mobility schemes, identified that $95 \%$ of HEl's and $92 \%$ of staff thought it an effective tool "to allow students who do not have the possibility to participate in a mobility scheme, to benefit from the knowledge" (Stohl, 2007, p. 149). However, Beelen and Jones (2015) have critiqued this assumption of a definitive link between mobility and the subsequent cascading of knowledge as suggested above. Whilst it may occur, there is little if any evidence available to say how and to what extent it takes place. As the surveys concentrate on the opinions of the staff who were the subjects of the mobility, the actual impact on the students is not measured in any way and the self-evaluations may well be subject to a certain degree of inflation in relation to that cascading of knowledge, in order for the staff member to justify their mobility to others.

\subsection{Notions of staff development through mobility?}

We can see that participants in the Erasmus+ mobility scheme are almost certainly meeting some, if not all of the basic tenets of andragogy as set out by Knowles (1980), particularly in the fields of selfmotivation and personal improvement through study, as evidenced in Chametzky (2014). It has also been shown that staff mobility is only effective when it is part of a deliberate process of staff development, as noted by Brewer and Leask (2012, p. 251). This research set out to ascertain how far the staff mobility process at THUAS and, in particular, the mobility undertaken as part of the ERASMUS Staff Exchange/Training Programme was part of a deliberate staff development process or fulfilled written and/or unwritten requirements.

If we examine Kennedy's typology of continuing professional development (2005, pp. 237-238) we can see that of the nine distinct identified types - training; award-bearing; deficit; cascade; standardsbased; coaching/mentoring; community of practice; action research; transformative - all could potentially be relevant to the experiences of those undertaking an exchange. In the cases studied here, however, it would seem that where there were any benefits to accrue in terms of personal development they could be found situated in the typologies of training; cascade; and community of 
practice. Any transformative elements that could be identified seemed to be solely incidental and not pre-planned, as we shall see below.

\section{Research}

\subsection{Methodology}

The purpose of the research was to understand the way in which ERASMUS staff mobility took place in THUAS, what the goals were and how the lack of a distinct policy may impact upon the experiences of those undertaking periods of mobility. By focusing on the following two research questions, i.e. (i) How is this type of mobility institutionalized at THUAS?; and (ii) What are the effects of this form of mobility on the actors and institution?, this aim was achieved.

In order to gain answers to these questions, semi-structured interviews were held, as they would give the opportunity for respondents to amplify their answers and for the researcher to ask for clarifications if necessary. In order to contact the relevant personnel, I requested from the International Office a list of all those staff members who had already undertaken an ERASMUS exchange or were scheduled to do so in the academic year 2018/19. Due to privacy concerns over issuing data I was not given a list of names to work with. Instead I had to produce an email text, outlining the scope and purpose of the project and requesting people to volunteer to be interviewed and also aiming for the snowball effect approach. This mail content was forwarded to the 32 staff members who were identified by the International Office as having undertaken ERASMUS exchanges during that academic year. This means that of the total THUAS academic staff, approximately $1.5 \%$ undertook a period of ERASMUS mobility in $2018 / 19$. The invitation to be interviewed was sent out via email and, due to a poor initial response rate, I subsequently asked that a reminder be forwarded to those same personnel. This elicited a total of 10 volunteers. Each of them were asked to fill in a short information form in order to limit the time needed for interviews and to eliminate those who may have been ineligible for whatever reasons.

Due to time clashes, etc., it was only possible to arrange interviews with 7 of those who volunteered. It was decided to proceed with the 7 available, and they form the self-reported evidence given below. Thus, approx. $22 \%$ of academic staff who took part in the ERASMUS mobility were interviewed. The interviews were first recorded, then fully transcribed. The questions asked were as shown in Supplementary Table 1. The seven interviewees were drawn from degree programmes across four faculties within THUAS. The interviewees undertook their mobility during the academic year 20182019 in the Czech Republic, Finland, France, Germany, Iceland, and Norway. Details of the respondents, the programmes they were from and the language of tuition in that programme, are shown in Supplementary Table 2. It is important to note that this study took place before the advent of COVID-19. Even though the sample size of this research is small, general preliminary conclusions can be made and further research is encouraged.

\section{Results}

At the request of the Erasmus+ National Agency for Education and Training, the Kohnstamm Instituut recently conducted a study into the impact of international mobility on professional development under Erasmust. They examined previous literature and official participatory reports of individuals undertaking staff mobility in order to try to establish how the mobility was viewed by participants (Verbeek, 2019). The reports suggested that impact rates with the experiences of undertaking mobility in 5 key areas (see Figure 1) ranged from moderate, through variable, to very high. For example, under the category of intercultural development, $90 \%$ of respondents reported an increase in their social, linguistic and/or cultural competences. Perhaps, as is the case with some of the respondents to the questions asked in the interviews below, the other $10 \%$ considered their cultural competences to be 
already very well developed. However, we have no concrete evidence nor way of measuring that this is, indeed, the case:

"If it had been someone else, maybe they would have learned more about the intercultural competences and things like that, but given that I've spoken the language since I was three and I did my PhD at that university in France, well not at all in that department but I did my PhD in France and everything, it wasn't such a cultural revelation; but still maybe on reflection maybe I would say that it certainly created a stronger bond and awareness with that institution." (Interviewee 5)

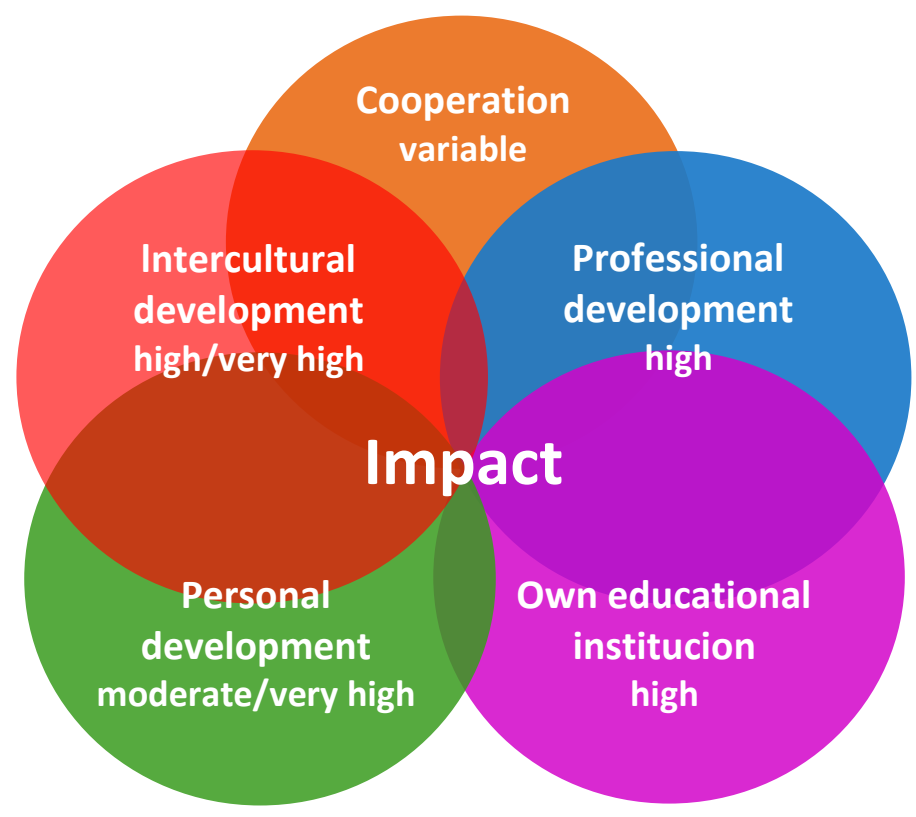

Figure 1 Impact of international mobility

Source: Verbeek (2019).

We can also see from the summary of Verbeek's work (see Figure 1; "Erasmus+," 2019) that there were a number of factors that were termed as contributing to Success, namely having an open attitude; involvement of supervisors/ management; affinity with the hosting partner institution; effective preparation; solid communication skills; and advance consideration of promotion and dissemination. Limiting factors were finances; workload; and the delegation or reallocation of tasks that the participant would not be able to perform at the home institution whilst undertaking a staff exchange. The Erasmus+ Higher Education Impact Study ("European Union," 2019, p. 119) shows that family and personal relationships (67\% reporting this as a limiting factor) and working responsibilities (64\%) were considered to be the main barriers hindering participation of staff who did not participate in mobility. Difficulties in finding an appropriate institution and or training/teaching programmes abroad; difficulty in being replaced if absent; and lack of information about the Erasmus+ programme and how it works, were all mentioned as barriers by more than $50 \%$ of people taking part in the survey for the impact study ("European Union," 2019, p. 120). We shall see below if the respondents in this case study also shared the same reflections on the positive and negative aspects of their exchange, or if they raised other issues.

So, if we examine Verbeek's success factors (Verbeek, 2019) in relation to our research subjects, we can immediately see that an open attitude was present in all respondents. No-one was 'forced' to go on exchange and all were to some extent volunteers. There was no doubt that as volunteers, they were already broadly in line with the aims of benefiting from an international exchange; however, as we shall see later, the reasons for them to do so varied. Some had specific tasks allocated to them whilst on the exchange, whereas others were free to negotiate their own tasks. Only one person was given 
explicit goals set by their management, whilst all of the respondents also set their own personal goals and, it would seem, broadly achieved them. Some colleagues were positively encouraged to go on exchange whilst others had to suggest it as a possibility. One in particular found it more of a struggle to get permission to go, and didn't always feel that the management wanted staff to be out of the department. As interviewee 1 commented:

"Well I think it has been seen as a, you can say, for [my] programme they don't like you to be away because when you are here you can solve all the problems." (Interviewee 1)

When examining the notion of involvement of supervisors/management in the planning of the process, one sees that involvement was in most cases often limited to signing forms and authorising the procedure. As interviewee 5 remarked:

"It was definitely my initiative... it wasn't really a meeting to discuss the substance of it, more the fact that it was being organised. The nature of the process is that you kind of have to sort of identify the partner, contact the partner and secure the potential opportunity, at which point you then just ask them permission to go, so in fact a lot of the contacts are predetermined about that stage - you know where you want to go, you know what you want to do, you have it all ready and then you ask for permission." (Interviewee 5)

This seems to be a missed opportunity to align Erasmus staff exchanges with the actual needs of the organisation as a whole and the programme in particular. It also seems to suggest that THUAS does not follow the practice of effective preparation, at least in the cases referred to in this study.

Nevertheless, it should be said that all the participants reported spending a great deal of time in preparing for their visit, both in terms of clarifying the desires of the host institution and in preparing teaching materials and other resources. One of the necessities that caused some concern with the respondents was the processes centred around the form filling required, not just in terms of the requirements from Erasmus itself but also the internal form filling and the lack of cohesive relationships with some of the support/service departments:

"Well, there could be improvements with the personnel department here in school. Human resources department, those are ..[pause]..they are really difficult sometimes. They are really difficult, but also because we are not used to them. We never have meetings with them." (Interviewee 4)

It was suggested that THUAS needed to designate someone to give advice on the procedure and also on the general organisation of a teaching mobility exchange.

"Somebody... who can tell you that [Pause] that's [sic] those are the priorities now and later you can think of that. That would help 'cause then you lose less time doing it." (Interviewee 6)

Another respondent also commented that: "I think they could simply make a checklist or a process diagram for the exchange quite simply to clarify the steps of the process and the documents required. Right now, it's very much about, you know, contacting individually for these updates, so it seems very repetitive that information needs to be given each time to the same person and it isn't provided in the form of a booklet or flyer or something. It's quite simple, you just need a process diagram and links to the specific forms and when they need to be done and handed in, but that's not a very clear process right now." (Interviewee 5)

It should be noted that this feedback was given by interviewee 5 to the mobility team of that programme, and that they have now produced an interactive document, complete with hyperlinks to all necessary documentation both internal to THUAS and external, etc., which addresses this request. This document would be easily adaptable for others to utilise should they choose to, if they have not done so already.

What can be derived from these findings is that in relation to the first research question, THUAS seems to lack some form of (strategic) alignment when it comes to mobility activities. Although mobility is 
often encouraged, it is not embedded in the institutional framework. Different (international) programmes approach these forms of mobility in different ways. Where one employee felt supported and even received explicit goals from their management team, another interviewee felt (active) pushback against their mobility plans. Staff mobility funded by Erasmus+ is thus envisaged in different ways within the programmes of THUAS and is not embedded or institutionalized. This is shown by the lack of a coherent, common and comprehensive staff exchange policy.

When one looks at the notion of affinity with hosting partner institution and how that pays dividends for THUAS, there were a number of positive reactions from the respondents:

"It's so good for me to know and to realise that there is more than one world." (Interviewee 4)

"I think it's really important to see a bit more than your own room that you are always in." (Interviewee 4)

"Well, it certainly helped me as a country tutor to build a relationship with the exchange coordinator there, so since then our communication and everything is much easier and much faster." (Interviewee 2)

Building relationships with one's counterpart at a partner institution allows for easier communication and can help in strengthening the bond between institutions and/or programmes.

"I think I really learned a lot in terms of professional skills, just the didactics of how different students respond very differently to THUAS students, to the way of teaching, [pause] to the way that I teach. I was able to immediately implement with our students and, because I dared to go deeper in terms of the content and higher in terms of the level, I realised when I came back that our students could in fact do that as well.

The whole way the university works was very different. So, there was a lot that I learned, cultural things but also how the university system works, how students respond, how you need to approach students differently from different cultures and backgrounds, if you have a not-sodiverse classroom as we are blessed with here. ... So, there was a lot that I learned during that exchange. I think." (Interviewee 3)

One of the things that we can see is that the funds are being used in an extremely productive way to allow lecturers to either undertake experimental teaching and learning strategies or see if the existing skills, methods and procedures they use in their teaching at THUAS are to any degree transferable to other contexts, environments and cohorts via opportunities afforded under the ERASMUS exchange, as evidenced from the answers of Interviewee 2, 3 and 7. One commented:

"I tested my elective there so it certainly added value in a way that I could see that one of my case studies was too long, or students found it too difficult or complex so I had to simplify it a bit for the course here. So, in that sense it really helped me to finalize my new elective [at THUAS]." (Interviewee 2).

Whilst another said "Testing [it] with a basically only [national] audience, there were two exchange students in there, it was very different." (Interviewee 3)

Clearly there are lessons to be learned here in relation to research question 2, as shown in the previous paragraphs, by developing intercultural competences and knowledge of other forms of pedagogy and also within the area of solid communication skills, both in terms of improving oneself as a part of the exchange experience and also by having a greater understanding of the learning experiences and needs of many students at THUAS who might benefit from this as well and, as was said:

"I would say my sensibility grew towards students from a non-Dutch background." (Interviewee 7)

This leads us to our last area of potentially successful impacts, consideration of promotion and dissemination in advance, and this is an area where our respondents seemed less happy. In this section 
we will also broaden this to explicitly include the dissemination of individual experiences postexchange, and the failure to often capitalise or celebrate the efforts of that person in contributing to the host institution while there, and to THUAS on their return. Not one of our seven respondents reported that they had been asked for a formal report by their line manager, and this was interpreted by some as downgrading their experience and the potential contributions that they could make to a programme in the future.

This lack of involvement at the programme manager level highlighted the lack of strategic thinking and planning going into this area. There appears to be a disconnect here with management at programme level, though one might conjecture that it is not at that level alone, which may not be totally their fault given that they are operating under time pressure and the need to prioritise more urgent problems, or 'firefighting', meaning that issues that are not immediately problematic, and paradoxically could add to the cache of the institution, are not addressed in the optimum way:

"I don't think it is because they don't want to or something. It is more that they don't realise that that is important and that there seems to be no time for this kind of exchange between management and colleagues..." (Interviewee 6)

However, that is not to say that those who undertook the exchange did not report back in various forms, normally to a group of colleagues, either by short written reports for newsletters or blogs or via verbal presentations to staff groups and colleagues. Thus, we can see at least some evidence of Kennedy's idea of personal development spreading beyond only the actual exchange participants via cascade training or information dissemination (Kennedy, 2005). However, some reported that due to the pressure of work and a plethora of other demands on their time, it was difficult to interest colleagues in listening and potentially benefiting from their experiences:

“... also among colleagues that's not very common, then you have your little group, the people who are interested in what you do, but it's not that you would be more curious as to what everybody does. We don't create opportunities where you have the time, more the, what do you call that, peace, room in your head to have it about that. Except we all talk about organisation of everyday life and all that, and we are eaten by it. I don't know how you say that in English." (Interviewee 6)

One of the interviewees felt that more should be made of recording and publicising the efforts of those who did a teaching exchange:

"Well stories actually, so stories like mine, I think that helps. Because I think if you hear someone show enthusiasm for an activity, that is a really good way for people to actually go and do it themselves. So, I think a collection of stories from teachers who have done it will actually be beneficial for others. So, he has done it and like me he is a teacher here as well, so I'm going to do it as well." (Interviewee 6)

This brings us to the limiting or more negative factors of finances, workload, and the delegation of tasks. In a sense it seems apposite to consider them all as belonging under the broad definition of resource allocation. Thus, we shall consider them as a package instead of individually and examine what suggestions our respondents had for reducing the effects of the limiting factors. When we speak of resources, we should not forget the opportunity costs inherent in taking part in such an exchange. If someone is abroad, then de facto they are generally unable to continue with their normal duties at the home institution, although some of their tasks which are capable of being performed remotely may well be expected of them, adding to the burden whilst on exchange and potentially taking time away from the cultural interactions they are there to experience. The very fact that they are away can lead to extra pressures on their return, with their work not being covered by others:

"There is quite a lot of time that goes into preparing a teaching exchange. Especially if you are going for an in-depth content programme, there is a lot of time teaching it there and you won't 
be getting a lot of work done for here [THUAS], and there is a lot that you need to catch up on when you come back." (Interviewee 3)

"What happened now for me at least was that I didn't get time off, so it means my work, sort of the week after, was twice the work load. [N]o one is going to say 'Oh you are going to [teaching exchange] so that means I am going to take your work for you'." (Interviewee 7)

When asked if they felt that many people could benefit from an Erasmus teaching mobility experience, there were mixed views about both the generality and also the methods of selection.

"[M]any of my colleagues also said, 'I don't think I could ever do that'. If that is already your basic attitude .... I don't think it will be beneficial to them and also, you know, if you are stressed already and you are going to teach stressfully, I don't see how that will benefit the students." (Interviewee 7)

"It's such a good experience, it teaches you so much and on different levels. Some of my colleagues are the adventurous ones, they go often, but the other ones, they should go. It's often our team leader that decides who is allowed to go or not to go. And sometimes I think she should have chosen other people. People that don't ask for much." (Interviewee 7)

Thus, whilst some programme managers may view a teaching exchange as a reward, others seem to view it as something to be undertaken on top of the tasks that one is contracted to perform. The idea of being rewarded for undertaking an exchange is one that does not seem to hold sway in THUAS. Indeed, some see it as anything but:

"To do it in your own free time doesn't really feel like a reward. No!" (Interviewee 1)

Three of our seven respondents had to either use their holiday allowance or take their DI hours (to be used for study leave, sabbaticals), even though the period of their teaching exchange did not exceed one week.

The notion of recognition, or should one say the lack of recognition, was one that was brought up by interviewees. Interviewees 2, 3, 5, and 6 all felt that it should be an integral part of the R\&O (Staff Performance Appraisal) scheme. At present, it is not formally recognised within it. Where it did form a part of the discussions, there seemed to be mixed reactions to how it was dealt with. Some clearly felt it did not receive the recognition it merited:

"Well, they only asked me did I go or not and I said 'yes' then they said 'ok then you have achieved your target for the year'. (laughs). Well, they seem to think it's great that you go on exchange but they don't really ask you to elaborate on it, or why was it great or what did you achieve there." (Interviewee 2)

"II]t was probably mentioned as one of the tasks I have, but discussed in the sense of how good was that or do you want to do more of that and blah blah blah. No." (Interviewee 6)

"... whilst others differed, and it was commented upon by one respondent that they did feel it was noteworthy and that "It was much appreciated that I went on staff exchange, it seemed to be highly valued. And I think it should be reflected in your R\&O cycle because it means you are doing something additional, something extra that other colleagues are maybe not willing to do." (Interviewee 3)

It is quite clear that the main intention of the Erasmus+ programme, namely increasing and sharing knowledge to further academic knowledge and the European Union sense of community, is achieved overall when looking at the responses given by the interviewees. They acknowledge that the programme provided them with (unique) experiences, which furthers their understanding and increases their ability to teach in an international setting. However, in relation to research question 2, because some basic (pre-)conditions are not met by THUAS, such as administrative support or setting clearly defined goals, the overall effect on the institution is mitigated. 


\section{Conclusion}

It is evident from the above that a range of questions become apparent. Despite the limited nature of the size and scope of this piece of research, the results would seem to indicate that there are opportunities to delve deeper into the issues raised in this brief document. Such issues could be split into two differing categories. Firstly institutional. What are the perceived advantages of academic mobility as viewed by the institution? Also, as previously noted above, what is the level of importance given to international mobility activities by managers. One can hypothesise that the level of importance might rise in programmes that are more internationally focused, or are taught through the medium of a language other than that of the sending institution, although this remains to be proven. What are the criteria for choosing certain individuals for mobility opportunities? What are the institutional goals that managers are seeking to meet when using mobility opportunities for their staff? For individuals, there are questions such as why those individuals choose to take up such opportunities and what they, as individuals, see as the benefits of doing so, and are those benefits realised? In addition, there is the effort to ascertain what support, training, or advice might be needed prior to the mobility. All of these areas are ripe for further in-depth research in order to give a clearer understanding of the place of mobility, including virtual mobility, in modern higher education.

To paraphrase de Wit, internationalisation is not a goal in itself but simply one tool that can be used to help improve the standard of educational experience for all. Clearly there is much to be improved around the operationalisation of ERASMUS mobility, although one should also be prepared to limit one's expectations of what one period of mobility can do to influence an individual, let alone to influence the effects upon a

The need for goal setting prior to a teaching exchange and evaluation on return to ensure it meets the goals of the individual and the institution. programme - especially when one considers the relatively small number of staff who undertake such periods of mobility. This should presumably spread out to more people in the next ERASMUS programme, which will emphasise the role of virtual mobility much more explicitly and thus may be more inclusive to the general staff, as well as to a far greater number of students, than the present scheme is. No doubt the shift to online course provision and the curtailing of the availability of travel inherent in the COVID-19 crisis will give further impetus to the notion of virtual exchange or internationalisation at home. This may help to reduce or remove the largest barriers hindering the participation of staff who did not participate in previous mobility as identified in the Erasmus+ Higher Education Impact Study ("European Union," 2019, p. 119), namely, family and personal relationships inhibiting the availability to travel, and the requirement of performing existing work responsibilities at the home institution.

\subsection{Recommendations}

The following are recommendations specifically focused on and drawn from research relating to staff mobility at THUAS. Whilst not necessarily directly transferable to other institutions, they may be of use as a starting point for analysis. Considering the research questions, when we evaluate the responses to Verbeek's (2019) factors for success and the limiting factors for staff mobility, we can identify areas that are ripe for improvement in order to make THUAS's use of ERASMUS+ staff mobility more efficient and effective, in order to further THUAS's goal of using internationalisation to increase the overall quality of the education provided. Whilst the following recommendations directly relate to the experiences in THUAS related above, they may also be applicable more generally to those in other institutions. It is hoped that their implementation would help, in however small a way, to increase the quality of education on offer.

It is thus recommended that there be further research both within THUAS and in a wider context in order to properly ascertain the situation with regard to academic staff mobility. THUAS should create 
a central policy that sets out criteria and goals for staff mobility and locates staff mobility within the notion of increasing the overall quality of the education provided, and also relates to notions of staff development under the broader policy of HRM. The policy, whilst central, should also maintain an element of flexibility in order to meet the needs and aspirations of individual programmes, student cohorts and individual staff members.

The possibility of ERASMUS staff mobility opportunities (particularly those of virtual mobility) be promoted more vigorously throughout THUAS to include those outside the 'mobile elite' with consideration being given to aiding those programmes where there is little or no academic staff mobility, in order to allow them to also benefit from such opportunities. The 'idea' of undertaking a teaching mobility should not only be encouraged within THUAS but form a recognised part of an academic's planned work hours, where personal circumstances allow. Time should be allocated to take advantage of a valuable and useful developmental tool which benefits both the institution and the individual. THUAS management should also be more aware of the potential for the piloting of new developments relating to curricula and pedagogical change whilst undertaking teaching mobility prior to implementing them at THUAS.

The goals for future teaching exchanges be set in conjunction with line managers and monitored on return. The reporting of exchange experiences need to be more effectively communicated and used as a learning tool for others. It is also imperative that a comprehensive review of mobility activities, both existing and potential, be undertaken and a coherent strategy for implementation be addressed at each level of the organisation. In order to be most productive, for the institution collectively as well as the individual staff, this strategy should be broad in focus, integrated into the overall goals of the degree programmes and be fully inclusive of all staff.

\section{Declaration of conflicting interests}

No potential conflict of interest is reported by the author.

\section{References}

Archer, M. S. (1995). Realist social theory: The morphogenetic approach. Cambridge: Cambridge University Press.

Beelen, J., \& Jones, E. (2015). Redefining internationalization at home. In A. Curaj, L. Matei, R. Pricopie, J. Salmi, \& P. Scott (Eds.), The European higher education area. Between critical reflections and future policies (pp. 59-72). London: Springer, Cham. https://doi.org/10.1007/978-3-319-208770

Brandenburg, U., de Wit, H., Jones, E., \& Leask, B. (2019). Internationalisation in higher education for society. $\quad$ Retrieved from https://www.universityworldnews.com/post.php?story=20190626135618704

Brewer, E., \& Leask, B. (2012). Internationalization of the curriculum. In D. Deardorff, H. de Wit, D. Heyl, \& T. Adams (Eds.), The Sage handbook of international higher education (pp. 245-266). Thousand Oaks, CA: Sage.

Cairns, D. (2017). The Erasmus undergraduate exchange programme: A highly qualified success story? Children's Geographies, 15(6), 728-740. https://doi.org/10.1080/14733285.2017.1328485

Chametzky, B. (2014). Andragogy and engagement in online learning: Tenets and solutions. Creative Education, 5(10), 813-821. https://doi.org/10.4236/ce.2014.510095

Cushner, K., \& Mahon, J. (2002). Overseas student teaching: Affecting personal, professional, and global competencies in an age of globalization. Journal of Studies in International Education, 6(1), 44-58. https://doi.org/10.1177/1028315302006001004 
Education and Culture-European Commission. (2015a). Erasmus - Facts, figures, and trends: The European support for student and staff exchanges and university cooperation in 2013-2014. Retrieved from https://ec.europa.eu/assets/eac/education/library/statistics/erasmus-plusfacts-figures_en.pdf

Education and Culture-European Commission. (2015b). Erasmust programme: Annual report 2014. Retrieved from https://ec.europa.eu/assets/eac/education/library/statistics/erasmus-plusannual-report_en.pdf

The new Erasmus+ starts here. (2021, January 11). Erasmus+ @ European Commission. Retrieved from https://ec.europa.eu/programmes/erasmus-plus/node_en

Erasmust. (2019). The impact of international mobility. On the professional development of teachers and other staff. Retrieved from https://www.erasmusplus.nl/sites/default/files/assets/Erasmus\%2B_factsheets_Impact_Intern ational_Mobility_2019_0.pdf

European Union. (2014). The Erasmus impact study. Effects of mobility on the skills and employability of students and the internationalization of higher education institutions. Executive Summary. Retrieved from https://ec.europa.eu/assets/eac/education/library/study/2014/erasmusimpact-summary_en.pdf

European Union. (2019). The Erasmus+ higher education impact study. Final report. Retrieved from https://op.europa.eu/en/publication-detail/-/publication/94d97f5c-7ae2-11e9-9f0501aa75ed71a1/language-en

Frisk, I. (2015). Developing personnel's internationalization competences through staff mobility: Case Hyria. (Master's thesis). Retrieved from https://www.theseus.fi/bitstream/handle/10024/103623/Frisk_llona.pdf;sequence=1

Hunter, F. \& De Wit H. (2015). What's in a name? Refocusing internationalisation of higher education EIEA. Retrieved from https://www.eaie.org/blog/whats-in-a-name-refocusinginternationalisation-of-higher-education.html

Jansone, I. A., \& Dislere, V. (2016). Counseling model for the promoting career development of ERASMUS mobility participants. British Journal of Education, Society \& Behavioural Science, 18(1), 1-13. https://doi.org/10.9734/BJESBS/2016/28954

Kennedy, A. (2005). Models of continuing professional development: A framework for analysis. Journal of In-Service Education, 31(2), 235-250. https://doi.org/10.1080/13674580500200277

Knight, J. (2004). Internationalization remodelled: Definition, approaches, and rationales. Journal of Studies in International Education, 8(1), 5-31. https://doi.org/10.1177/1028315303260832

Knowles, M. (1980). The modern practice of adult education: From pedagogy to andragogy. Chicago, IL: Follett Publishing Company.

Leask, B. (2015). Internationalizing the curriculum. London: Routledge.

Leask, B., Beelen, J. \& Kaunda, L. (2013). Internationalisation of the curriculum: International approaches and perspectives. In H. de Wit, F. Hunter, L. Johnson, \& H. G. van Liempd (Eds.), Possible futures: The next 25 years of internationalisation of higher education (pp. 187-203). Amsterdam: European Association for International Education.

Leung, M. W. H. (2013). 'Read ten thousand books, walk ten thousand miles': geographical mobility and capital accumulation among Chinese scholars. Transactions of the Institute of British Geographers, 38(2), 311-324. https://doi.org/10.1111/j.1475-5661.2012.00526.x

Lourenço, M. (2018). Internationalizing teacher education curricula: Opportunities for academic staff development. On the Horizon, 26(2), 157-169. https://doi.org/10.1108/OTH-07-2017-0053 
Pett, S. (2015). It's time to take the curriculum back from dead white men. Retrieved from https://theconversation.com/its-time-to-take-the-curriculum-back-from-dead-white-men40268

Quezada, R. L. (2012). Internationalization of teacher education: Creating globally competent teachers and teacher educators for the 21st century. London, UK: Routledge.

Sawir, E. (2011). Academic staff response to international students and internationalising the curriculum: The impact of disciplinary differences. International Journal for Academic Development, 16(1), 45-57. https://doi.org/10.1080/1360144X.2011.546224

Schleicher, A. (2012). Preparing teachers and developing school leaders for the 21st century: Lessons from around the world. Paris: OECD Publishing.

Stohl, M. (2007). We have met the enemy and he is us: The role of the faculty in the internationalization of higher education in the coming decade. Journal of Studies in International Education, 11(3/4), 359-372. https://doi.org/10.1177/1028315307303923

Sursock, A. (2015). Trends 2015: Learning and Teaching in European Universities. Brussels: European university association.

Verbeek, F. (2019). De opbrengsten van internationale mobiliteit voor de professionele ontwikkeling van onderwijsmedewerkers. Retrieved from https://www.erasmusplus.nl/sites/default/files/assets/Rapportage\%20mobiliteit\%20onderwijs medewerkers_28052019_0_0.pdf

Vorster, J.-A., \& Quinn, L. (2017). The "decolonial turn": What does it mean for academic staff development? Education as Change, 21(1), 31-49. https://doi.org/10.17159/1947$9417 / 2017 / 853$

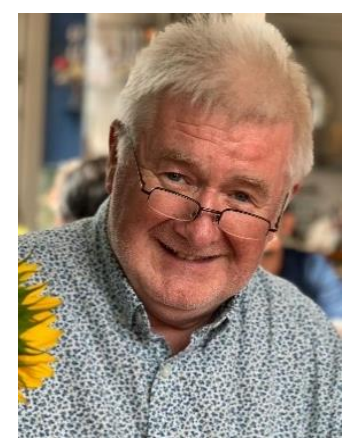

Paul G. Nixon is a Principal Lecturer in Political Science at The Hague University of Applied Sciences and co-ordinator of The Hague Network Virtual Exchange. He is a Visiting Professor at Masaryk University, Brno, Czech Republic. His work is situated on the interface between technology and society. He has contributed chapters to many edited collections on the use of ICTs, particularly in the fields of political parties, electronic democracy and social welfare. He has previously co-edited ten collections, the most recent of which are Reshaping International Teaching and Learning in Higher Education (with V. P. Dennen and R. Rawal, 2021), Sex in the Digital Age (with I. K. Dusterhoft, 2018), and Digital Media Use Across the Lifecourse (with R. Rawal and A. Funk, 2016). 


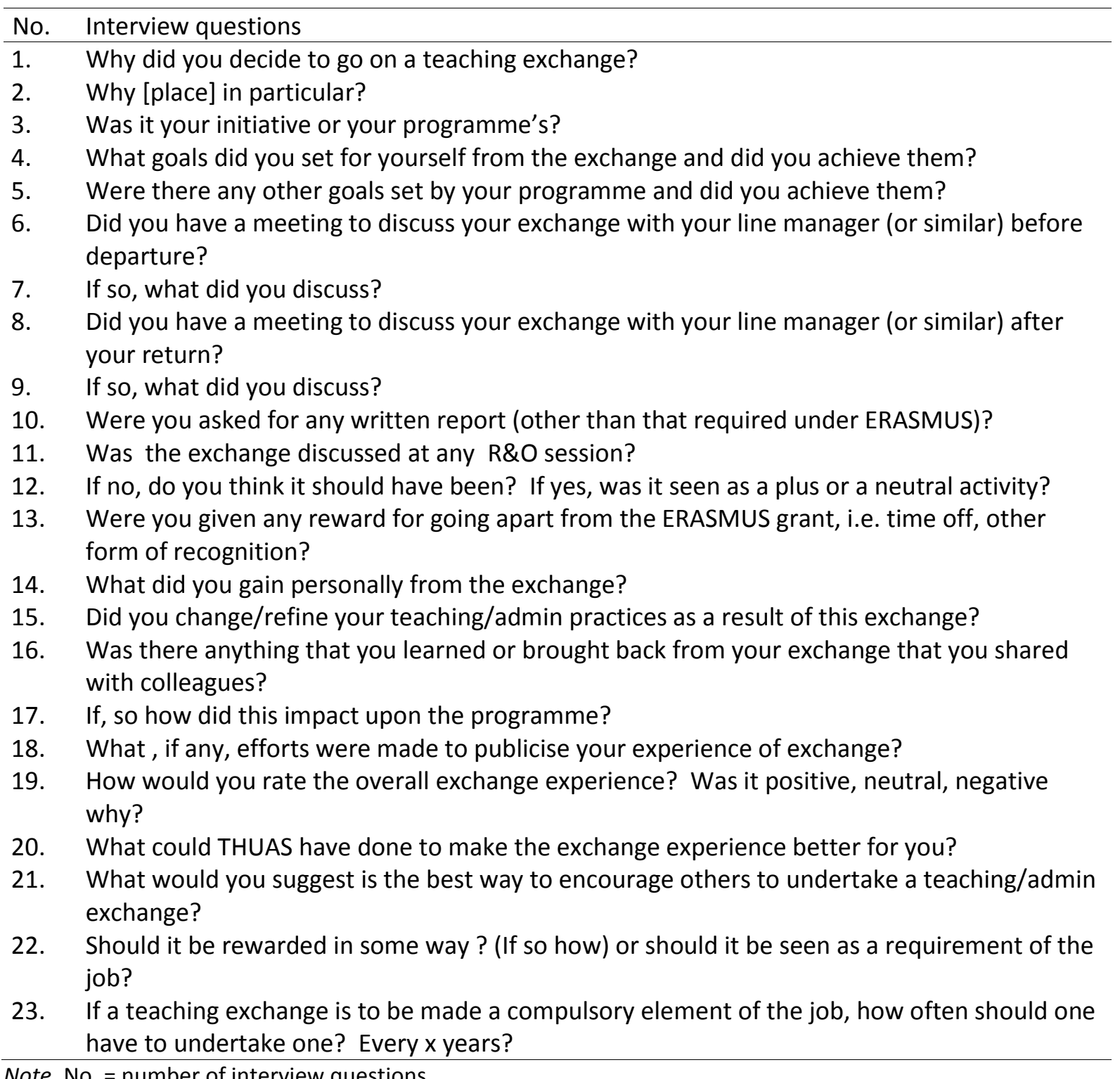
Note. No. $=$ number of interview questions. 
Supplementary Table 2. Interview subjects

\begin{tabular}{lll}
\hline No. & Programme (language of instruction) & Country of mobility \\
\hline 1. & International Communication Management (English) & Czech Republic \\
2. & European Studies (English) & Iceland \\
3. & European Studies (English) & Iceland, Czech Republic \\
4. & Communication and Multi Media Design (Dutch) & Germany \\
5. & European Studies (English) & France \\
6. & Social Work (Dutch) & Germany \\
7. & ICT (Dutch) & Norway \\
\hline
\end{tabular}

Note. No. = number of subjects. 